\title{
Supervisi Akademik Kepala Sekolah Dan Pengasuh Pondok Pesantren Dalam Meningkatkan Proses Pembelajaran Pendidikan Agama Islam
}

\author{
Muh Banjari ${ }^{1}$, Lukman Hakim² \\ 1Program Pascasarjana IAIN Salatiga Email: muhbanjari4@gmail.com \\ 2Program Pascasarjana IAIN Salatiga Email: 1urah1123@gmail.com
}

\begin{abstract}
ABSTRAK
Penelitian ini bertujuan untuk mengetahui metode, penerapan, faktor penghambat dan pendukung supervisi akademik kepala sekolah dan pengasuh pondok pesantren dalam meningkatkan proses pembelajaran PAI. Penelitian ini menggunakan metode pendekatan kualitatif jenis fenomenologi. Tenik pengambilan data melalui dokumentasi dan wawancara. Sedangkan analisis data penelitian ini menggunakan kualitatif yang bersifat induktif. Hasil penelitian menyimpulkan bahwa pertama, Supervisi akademik kepala sekolah dan pengasuh menggunakan metode pendekatan kolaboratif. Teknik supervisi yang digunakan, menggunakan dua teknik yaitu teknik individu dan kelompok. Teknik individu meliputi: kujungan kelas, observasi dan pertemuan individu. Teknik kelompok dengan mengadakan rapat dan pelatihan guru untuk meningkatkan kompetensi guru. Kedua, Penerapan supervisi akademik diterapkan kepada semua guru dan staf. Dilaksanakan pada awal tahun ajaran baru, setiap bulan secara terjadwal dan tidak terjadwal (insidental). Ketiga, faktor penghambat meliputi: (a) waktu pelaksanaannya tidak sesuai dengan jadwal, (b) faktor kesehatan guru dan supervisor, (c) faktor sosial guru yang disupervisi usianya lebih tua dari supervisor. Faktor pendukung meliputi: (a) faktor keterbukaan guru, (b) kepala sekolah dan pengasuh pondok pesantren dapat mengontrol, membimbing dan mengembangkan keterampilan guru, (c) kepala sekolah dan pengasuh pondok pesantren termotivasi untuk beribadah meningkatkan kualitas sumber daya manusia yang beriman dan bertaqwa.
\end{abstract}

Kata kunci: Supervisi Akademik, Kepala Sekolah, Proses Pembelajaran Pendidikan Agama Islam

\section{ABSTRACT}

This study aims to determine the method, application, inhibiting factors and supporting academic supervision of principals and caregivers of Islamic boarding schools in improving the learning process of Islamic Education. This study uses a phenomenological qualitative approach. The technique of data collection through documentation and interviews. While the data analysis of this study uses qualitative, inductive. The results of the study concluded that first, the academic supervision of principals and caregivers used a collaborative approach. The supervision technique used two techniques, namely individual and group techniques. Individual techniques include: class visits, observations and individual meetings. Group techniques by holding teacher meetings and training to improve teacher competency. Second, the application of academic supervision is applied to all teachers and staff. Conducted at the beginning of the new school 
year, every month on a scheduled and unscheduled basis. Third, inhibiting factors include: (a) the time of implementation is not in accordance with the schedule, (b) the health factor of the teacher and supervisor, (c) the social factors of the teacher supervised by the age of the supervisor. Supporting factors include: (a) the teacher's openness factor, (b) the principal and caregiver of the boarding school can control, guide and develop the skills of the teacher, (c) the principal and caregivers of the boarding school are motivated to worship to improve the quality of faithful and devoted human resources.

Keywords: Academic Supervision, Principal, Religious Education Learning Process

Article history:

Received: 30-7-2019

Revised: $10-11-2019$

Accepted: 27-2-2020

\section{PENDAHULUAN}

Pendidikan adalah usaha sadar dan terencana untuk mewujudkan suasana belajardan proses pembelajaran agar peserta didik secara aktif mengembangkan potensi dirinya untuk memiliki kekuatan spiritual keagamaan, pengendalian diri, kepribadian, kecerdasan, akhlak mulia, serta keterampilan yang diperlukan dirinya, masyarakat, bangsa dan negara. (Undang-Undang Republik Indonesia Nomor 20 Tahun 2003 Tentang Sistem Pendidikan Nasional).

Tugas guru dalam proses pembelajaran dan pendidikannya, esensi pembelajaranya harus memiliki tiga sasaran hasil belajar, yaitu: tumbuhnya pengetahuan baru, tumbuhnya kemampuan baru, tumbuhnya perubahan baru
(Fathurrohman dan Suryana 2011:

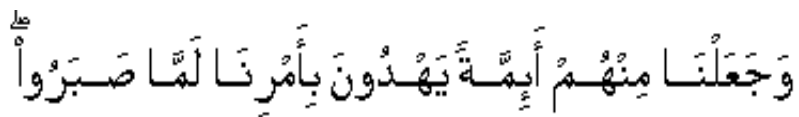

V-VI). Kepemimpinan di lembaga sekolah yang diperankan kepala sekolah mempengaruhi orang lain seperti guru dan personel sekolah untuk mencapai tujuan yang diinginkan. Tujuan yang akan tercapai jika kepala sekolah mau dan mampu membangun komitmen dan bekerja keras untuk menjadikan sekolah yang dipimpinnya menjadi sekolah yang berkualitas dan menjadi terbaik di daerahnya (Sagala, 2012: 124).

Kepala sekolah sebagai pemimpin berperan untuk memberikan batuan kepada guru dalam menghadapi kesulitan dalam proses pembelajaran, dengan memberikan petunjuk dan pengarahan kepada guru-guru 
sebagai mana firman Allah swt dalam surat As Sajdah ayat 24:

Artinya:

"Dan Kami jadikan diantara mereka itu pemimpinpemimpin yang memberi petunjuk dengan perintah Kami selama mereka sabar (Kementrian Agama RI, 2012: 589).

Sagala

mengungkapkan

pengawasan penting sekali dilakukan kepala sekolah untuk menjamin bahwa layanan pendidikan atau layanan belajar terus menerus membaik (Sagala, 2012: 132). Dalam proses supervisi, supervisor dapat berperan sebagai sumber informasi, sumber ide, sumber petunjuk dalam berbagai hal dalam rangka peningkatan kemampuan profesional guru. Supervisi sebagai evaluasi, untuk mengetahui kemampuan guru yang akan dibina perlu dilakukan evaluasi sehingga program supervisi cocok dengan kebutuhan guru (Kompri, 2015: 196-197)

Supervisi akademik adalah serangkaian kegiatan membantu guru mengembangkan kemampuannya mengelola proses pembelajaran demi pencapaian tujuan pembelajaran (Dharma, 2008: 9). Oleh karena itu, kegiatan supervisi akademik dipandang perlu untuk meningkatkan kompetensi profesional guru termasuk guru PAI dalam proses pembelajaran.

Guru Pendidikan Agama Islam merupakan salah satu guru di Sekolah menengah tingkat pertama yang mempunyai peran penting dalam pembentukan akhlak dan karakter anak. Guru PAI mempunyai pengawas dari Kementrian Agama, namun hal ini tidak maksimal sehingga perlu peran Kepala Sekolah dalam memberikan supervisi.

Suharsimi mengemukakan bahwa dalam kenyataannya kepala sekolah belum dapat melaksanakan supervisi dengan baik dengan alasan beban kerja kepala sekolah yang terlalu berat serta latar belakang pendidikan yang kurang sesuai dengan bidang studi yang disupervisi (Suharsimi, 2004: 4). Sehingga tujuan untuk membina dan membimbing guru masih belum sempurna serta guru kurang memahami makna dari pentingnya supervisi yang dilakukan oleh kepala sekolah.

Upaya peningkatan proses pembelajaran Pendidikan Agama Islam di sekolah berbasis pondok pesantren bukan masalah yang 
sederhana, tetapi memerlukan penanganan yang multidimensi dengan melibatkan berbagai pihak yang terkait. Untuk mencapai hal itu, kepala sekolah dan pengasuh pondok pesantren melakukan berbagai upaya diantaranya adalah dengan meningkatkan kemampuan supervisi akademik kepala sekolah.

Menurut Glickman, supervisi akademik adalah serangkaian kegiatan membantu guru mengembangkan kemampuannya mengelola proses pembelajaran demi pencapaian tujuan pembelajaran (Dharma, 2008: 9). Supervisi akademik adalah bantuan profesional kepada guru, melalui siklus perencanaan yang sistematis, pengamatan yang cermat, dan umpan balik yang objektif dan segera (Mulyasa, 2013: 249).

Kepala sekolah adalah seorang fungsional guru yang diberi tugas untuk memimpin suatu sekolah dimana diselenggarakan proses belajar mengajar, atau tempat dimana terjadi interaksi antara guru yang memberi pelajaran dan murid yang menerima pelajaran (Makawimbang, 2012: 61). Pembelajaran adalah proses interaksi antara peserta didik dengan lingkunganya yang membangun interaksi secara penuh (Sagala, 2012: 62).

Pendidikan Agama Islam Menurut Abdurrahman al Nahwawi dalam Abdullah, pendidikan islam merupakan suatu proses penataan individual dan sosial yang menjadikan seseorang tunduk dan taat sekaligus menerapkan Islam secara sempurna dalam kehidupan individu dan masyarakat (Idi dan Suharto, 2006: 47).

Perilaku profesional akan lebih diwujudkan dalam diri guru, apabila institusi tempat ia bekerja memberi perhatian lebih banyak pada pembinaan, pembentukan, dan pengembangan sikap profesional (Karwati dan Priansa, 2013: 215). Oleh karena itu kepala sekolah harus menguasai konsep supervisi akademik. Supervisi merupakan aktivitas yang harus dilakukan oleh seorang pemimpin berkaitan dengan peran kepemimpinan yang diembannya dalam rangka menjaga kualitas produk yang dihasilkan lembaga (Arikunto dan Yuliana, 2008: 370). Kepala sekolah dalam melaksanakan supervisi harus memiliki tujuan. Menurut Glickman dalam Donni Juni Priansa dan Rismi 
Somad, Secara umum, tujuan supervisi akademik adalah membantu guru untuk mengembangkan kemampuannya dalam mencapai tujuan pembelajaran yang direncanakan bagi peserta didiknya (Priansa dan Somad, 2014: 108). Tujuan pembelajaran adalah harapan perubahan yang dicapai oleh peserta didikdari adanya proses pembelajaran (Faturrohman, 2012: 12).

Dalam pelaksanaan supervisi akademik kepala sekolah harus mampu menguasai semua aspek supervisi akademik. Keberhasilan pembelajaran guru di pengaruhi oleh kepala sekolah sebagai seorang pemimpin dalam melakukan supervisi dan pembinaan terhadap guru agar tujuan proses pembelajaran dapat berjalan dengan baik.

\section{METODE PENELITIAN}

Penelitian merupakan penelitian kualitatif diskriptif yang mendiskripsikan metode, penerapan, faktor penghambat dan pendukung supervisi akademik yang dilakukan kepala sekolah dan Pengasuh Pondok
Pesantren. Subyek penelitian Kepala sekolah, Pengasuh Pondok Pesantren dan guru PAI di MTs Pondok Pesantren Al-Mu'min Tembarak Temanggung. Metode pengumpulan data yaitu dengan wawancara dan dokumentasi. Metode analisis data menggunakan analisis data kualitatif bersifat induktif yaitu analisis berdasarkan data yang diperoleh, selanjutkan dikembangkan pola hubungan tertentu atau menjadi hipotesis.

\section{HASIL PENELITIAN DAN PEMBAHASAN}

\section{A. Metode Supervisi Akademik Kepala Sekolah Dan Pengasuh Pondok Pesantren}

Kompetensi supervisi akademik pengawas merupakan aspek yang paling strategis karena bersentuhan langsung dengan kopetensi guru. Prilaku siswa sangat dipengaruhi oleh prilaku guru, prilaku guru dalam pembelajaran dipengaruhi oleh prilaku pengawas (Masaong,2013: 71). Untuk itu perlu pemilihan metode dan teknik supervisi yang tepat. Berdasarkan temuan yang ada di lapangan metode supervisi kepala sekolah dan pengasuh pondok pesantren. Sebagaimana yang 
disampaikan oleh kepala MTs Pondok Pesantren Al-Mu'min bapak SS dalam wawancara bahwa: "Metode pendekatan yang kami gunakan menggunakan metode pendekatan secara kolaboratif, memberikan masukan dan bimbingan kepada guru terkait. Kemudian kami menggunakan teknik supervisi individu dan kelompok. Tenik supervisi individu kami menggunakan teknik kujungan kelas, observasi dan pertemuan individu. Teknik supervisi kelompok kami mengadakan rapat tahunan dan rapat bulanan, selain itu kami juga mengadakan pelatihan guru untuk meningkatkan kompetensi guru" (Data Wawancara dengan SS pada hari Rabu, 20 Februari 2019).

Pengasuh pondok pensantren Al-Mu'min Ustadz SR juga menyampaikan metode yang digunakan dalam mensupervisi akademik guru PAI dalam wawancara: "Metode pendekatan yang kami gunakan menggunakan pendakatan langsung dan tidak langsung. Peneliti secara langsung meberikan bimbingan kepada guru melalui rapat bulanan dan secara tidak langsung kami meminta informasi dari kepala kesantrian 96 maupun dengan melihat santri dalam praktek ibadahnya. Teknik yang kami gunakan kadang individu kadang kelompok. Sesuai dengan permasalah dari hasil pengamatan dan informasi yang kami dapat dari kepala kesantrian atau kepala pendidikan. Contoh umpamanya dalam pengajaran gurunya dalam menjelaskan kurang tepat atau metode atau cara pengajarannya kurang tepat dalam menyampaikanya maka kami memanggil guru tersebut secara pribadi untuk meberi arahan dan bimbingan bagaimana mengajar yang baik, tetapi saya tidak menentukan waktu dan tempatnya. Kalau kelompok bimbingan pada rapat pimpinan. yang kemudian disampaikan melalui mundir kepada semua guru" (Data Wawancara dengan SR pada hari Rabu, 20 Februari 2019)

Metode pendekatan yang digunakan dalam supervisi akademik yang dilakukan kepala sekolah dan pengasuh pondok pesantren di MTs Al-Mu'min Tembarak Temanggung yaitu: 
1. Metode pendekatan kolaboratif

\section{Pendekatan kolaboratif} adalah cara pendekatan yang memadukan cara pendekatan direktif dan nondirektif menjadi pendekatan baru (Maunah, 2009: 140). Pada pendekatan ini baik supervisor maupun guru bersama-sama, bersepakat untuk menetapkan struktur, proses dan kriteria dalam melaksanakan proses percakapan terhadap masalah yang dihadapi guru. Perilaku supervisor adalah sebagai berikut: menyajikan, menjelaskan, mendengarkan, memecahkan masalah, dan negosiasi. Pendekatan ini biasa digunakan oleh supervisor untuk mensupervisi kepada guru yang profesional (Snae dkk, 2016: 85). Di MTs Podok Pesantren AlMu'min Muhammadiyah Tembarak Temanggung guru PAI semuanya sudah senior, sudah lama mengajarnya. Sehingga dalam pelaksanaan supervisi saling mempengarui, bertanggung jawab, saling berperan dalam pemecahan masalah dilakukan secara bersama.

2. Teknik supervisi akademik
Berdasrkan data hasil wawancara dengan kepala sekolah maupun pengasuh pondok pesantren di MTs Podok Pesantren Al-Mu'min Muhammadiyah Tembarak Temanggung mengunakan dua teknik supervisi yaitu teknik supervisi individu dan teknik supervisi kelompok.

a. Teknik supervisi individu

Teknik supervisi individual adalah supervisi yang diberikan kepada guru tertentu yang mempunyai masalah khusus dan bersifat perorangan (Suwithi dkk, 2016: 28). Teknik individu yang digunakan di MTs Podok Pesantren Al-Mu'min Muhammadiyah Tembarak Temanggung yaitu:

1). Kunjungan kelas

Dalam kegiatan ini kepala sekolah masuk kedalam ruangan kelas dengan membawa intrumen penilaian supervisi. Untuk melihat kesiapan dalam pelaksanan proses pembelajaran. Seperti memeriksa kelengkapan admistrasi pembelajaran RRP, jurnal mengajar, absensi, instrumen penilaian. Selain administrasi kepala sekolah juga 
mengamati jalanya proses pembelajaran untuk melihat apa kekurangan atau kelemahan yang sekiranya perlu diperbaiki. Kemudian kepala sekolah bersama guru mengadakan perjanjian untuk membicarakan hasil-hasil observasi, dan tahap tindak lanjut.

2). Obsevasi kelas

Dalam

pelaksanaan

obsevasi kelas yang dilakukan kepala sekolah dan pengasuh pondok pesantren MTs Podok Pesantren

Al-Mu'min

Muhammadiyah dilakukan dengan tidak terjadwal. Sewaktuwaktu kepala sekolah dan pengasuh pondok pesantren lansung datang ke kelas untuk melihat guru PAI yang sedang mengajar. Seperti yang diungkapkan oleh pengasuh pondok pesantren bapak SR dalam wawancaranya:"Kemudian yang tak terjadwal saya sewaktuwaktu saya langsung datang melihat lihat Guru PAI yang sedang mengajar bagaimana mengajarnya atau metode yang di gunakan dalam mengajar. (insidental)" (Data Wawancara dengan SR pada hari Rabu, 20 Februari 2019).

Semua guru PAI yang ada di MTs Podok Pesantren AlMu'min Muhammadiyah dituntut untuk selalu siap dan profesional dalam melaksanakan proses pembelajaran.

3). Pertemuan Individu

Dalam pertemuan individu kepala sekolah dan pengasuh pondok pesantren MTs Podok Pesantren Al-Mu'min Muhammadiyah Tembarak Temanggung memanggil guru yang mempunyai permasalahan dalam proses pembelajaran di tempat yang sudah di sepakati. Dalam pertemuan ini kepala sekolah dengan guru, pengasuh pondok pesantren dengan guru bersama-sama berdiskusi mencari solusi jalan keluar terhadap masalah yang dihadapi guru tersebut. Selain itu kepala sekolah dan pengasuh pondok pesantren memberikan bimbingan dan memotivasi agar ada perbaikan dalam proses pembelajaran. 
b. Teknik supervisi kelompok

Teknik supervisi kelompok adalah satu cara melaksanakan program supervisi yang ditujukan pada dua orang atau lebih, memiliki masalah atau kebutuhan atau kelemahan-kelemahan yang sama dikumpulkan menjadi satu/bersama-sama (Suwithi dkk, 2016: 30). Teknik supervisi kelompok yang digunakan di oleh kepala sekolah dan pengasuh pondok pensantren MTs Podok Pesantren Al-Mu'min

Muhammadiyah Tembarak Temanggung adalah:

\section{1). Mengadakan rapat}

Rapat merupakan salah satu kegiatan supervisi kelompak yang dilakukan oleh kepala sekolah maupun dari pengasuh pondok pesantren MTs Podok Pesantren Al-Mu'min Muhammadiyah Tembarak Temanggung untuk memberikan bimbingan dan pemecahan masalah yang ada dalam pelaksanaan proses pembelajaran. Dalam rapat ini semua permasalahan yang berkaitan dalam pembelajaran di munculkan kemudian dibahas secara bersama untuk memberikan penyelesaian atau jalan keluar terhadap masalah yang dihadapi oleh guru tersebut. Di dalam rapat hubungan antara guru dengan kepala sekolah sangat harmonis karena adanya keterbukaan dan saling menghormati satu dengan yang lainya.

2). Mengadakan pelatihan

Mengadakan pelatihan merupakan salah satu cara dari kepala sekolah MTs Pondok Pesantren Al-Mu'min Muhammadiyah Tembarak Temanggung membantu guru dalam mengembangkan kompetensi tertentu yang dianggap masih rendah. Tujuan dari mengikutkan guru dalam pelatihan ini adalah untuk meningkatkan kopetensi guru agar lebih baik sehingga dalam pengolahan proses pembelajaran akan meningkat. Secara otomatis apabila proses pembelajaran meningkat akan mempengaruhi dari hasil pembelajaran.

\section{B. Perencanaan Supervisi Akademik Kepala Sekolah dan Pengasuh Pondok Pesantren}


Perencanaan program supervisi akademik adalah penyusunan dokumen perencanaan, pemantauan serangkaian kegiatan membantu guru mengembangkan kemampuannya mengelola proses pembelajaran untuk mencapai tujuan pembelajaran (Prasojo dan Budiyono, 2011: 99).

Kepala MTs Pondok Pesantren Al-Mu'min Muhamadiyah Tembarak Temanggung, menyusun perencanaan supervisi akademik di awal tahun pelajaran baru. Perencanaan ini diwujudkan dalam program supervisi akademik. Supervisi ini lebih ditekankan kepada semua guru mata pelajaran seperti guru Pendidikan Agama Islam. Program supervisi akademik ini sangat penting bagi kepala sekolah sebagaimana disampaikan bapak SS dalam wawancara bahwa: "Perencanaan supervisi akademik kami buat dalam bentuk program supervisi. Program supervisi akademik itu sangat penting, karena sebagai acuan dalam melaksanakan supervisi. Dalam pembuatan perencanaan saya selalu koordinasi dengan pihak pondok pesantren yang diwakili oleh kepala bidang pendidikan yaitu ustadz Makmun pada waktu rapat kerja (raker) awal tahun. Dan dalam pelaksanaan supervisi saya koordinasi dengan bagian akademik. Program supervisi ini juga saya sosialisasikan kepada semua guru dan kariyawan pada waktu rapat tahun ajaran baru. Hal ini dimaksudkan agar guru dan karyawan juga memahami maksud dan tujuan program supervisi akademik ini" (Data Wawancara dengan SS pada hari Rabu, 20 Februari 2019).

Dalam menyusun rencana supervisi akademik kepala sekolah berkoordinasi dengan pihak pondok pesantren MTs Al-Mu'min bagian akademik yang diwakili oleh ustadz makmun bersama-sama menentukan hal-hal yang berkaitan dalam pelaksanaan supervisi yaitu: Menentukan masalah yang akan di supervisi, Menentukan tujuan supervisi akademik, Indikator yang akan di supervisi, Waktu pelaksanaan supervisi, Tempat pelaksanaan supervisi, Menentukan metode dan teknik supervisi, Penilain dan intrumen. Setelah rencana pelaksanaan supervisi dibuat kemudian disosialisasikan oleh kepala sekolah kepada semua guru pada rapat tahun ajaran baru. 
Dengan tujuan agar semua guru mengetahui jaduwal kunjungan, memahami maksud tujuan pelaksanaan program supervisi akademik ini, tentu guru dengan senang mempersiapkan terkait pembelajaran yang akan dilaksanakan. Guru dan kepala sekolah memiliki persepsi yang sama dan saling tanggung jawab.

Kepala sekolah MTs Al-Mu'min Muhamadiyah Tembarak Temanggung merencanakan pelaksanaan supervisi akademik terhadap guru PAI setiap awal tahun ajaran baru dan setiap bulan hal ini dilakukan untuk melihat perkembangan dan perubahan yang dilakukan guru dalam proses pembelajaran.

\section{Pelaksanaan}

\section{Supervisi}

\section{Akademik Kepala Sekolah dan Pengasuh Pondok Pesantren}

Berdasarkan temuan di lapangan bahwa pelaksanaan supervisi akademik kepala sekolah dan pengasuh pondok pesantren di MTs Pondok Pesantren Al-Mu'min Muhammadiyah Tembarak Temanggung dilaksanakan setiap tahun ajaran baru setiap bulan dan diterapkan kepada semua guru. Seperti disampaikan oleh kepala sekolah MTs Al-Mu'min bapak SS dalam wawancara:"Supervisi akademik yang ada di sekolahan kami, penerapanya adalah pada awal tahun ajaran baru (raker) kami sampaikan program-program supervisi kepada semua guru dan staf termasuk guru PAI, kemudian setiap bulan tanggal sembilan kami melaksanakan rapat, tentunya membahas temuan masalah yang menunjang pembelajaran, kemudian di bahas bersama-sama pendekatan dan rencana tindak lanjut" (Data Wawancara dengan SS hari Rabu, 20 Februari 2019).

Pengasuh pondok pensantren Al-Mu'min Ustadz SR juga menyampaikan penerapan supervisi akademik yang ada di sekolahan MTs Pondok Pesantren Al-Mu'min dalam wawancara:"Terjadwal dan tidak terjadwal masudnya gini mas yang terjadwal kami laksanakan setiap tanggal lima untuk bimbingan semua pimpinan dan tanggal sembilan untuk semua staf dan guru PAI. Kemudian yang tak terjadwal saya sewaktu-waktu saya langsung datang melihat-lihat Guru PAI yang sedang mengajar bagaimana mengajarnya 
atau metode yang di gunakan dalam mengajar (insidental)" (Data Wawancara dengan SR hari Rabu, 20 Februari 2019).

Penerapan supervisi akademik di MTs Pondok Pesantren Al-Mu'min diterapkan kepada semua guru dan staf. Menitik beratkan pada supervisi administrasi dan proses pembelajaran. Pelaksanaannya pada awal tahun ajaran baru dan setiap bulan. Pada tahun ajaran baru kepala sekolah menggunakan pendekatan kolaboratif dan teknik supervisi kelompok yaitu dengan mengadakan rapat dalam rapat kepala sekolah memberikan bimbingan kepada semua guru dalam penyusunan administrasi kelas seperti Prota, Promes, RRP, Silabus, intrumen penilain dan administrasi lainya yang menunjang proses pembelajaran serta penggunaan strategi pembelajaran.

Selain dilaksanakan pada awal tahun ajaran baru pelaksanaan supervisi juga dilaksanakan pada setiap bulan secara terjadwal maupun tidak terjadwal (insidental) dengan menggunakan metode pendekatan kolaboratif dan teknik kelompok maupun individu. Pada setiap bulan pelaksanaan supervisi 102 akademik kepala sekolah pada tanggal lima dan tanggal sembilan dengan menggunakan teknik kelompok melalui rapat. Dalam rapat ini dibahas temuan-temuan permasalahan yang dihadapi oleh guru dalam proses pembelajaran, kemudian dibahas bersama-sama untuk mencari solusi jalan keluar terhadap permasalahan yang menunjang pembelajaran. Kepala sekolah dan pengasuh pondok pesantren memberikan bimbingan dan memberikan motivasi kepada guru dengan tujuan untuk menigkatkan kompetensi guru. Kepala sekolah juga menyampaikan rencana tidak lanjut terhadap permasalahan yang dihadapi guru dalam proses pembelajaran. Untuk meningkatkan kopentensi guru yang masih kurang kemampuannya, maka pihak sekolah mengikutsertakan pelatihan guru dalam meningkatkan kompetensi guru dalam pengelolaan proses pembelajaran.

Kepala sekolah dan pengasuh pondok pesantren melaksanakan supervisi akademik dengan menggunakan teknik individu. Dalam pelaksanaanya kepala sekolah mengunakan intrumen dan penilain supervisi. Tenik individu yang sering 
digunakan adalah kunjungan kelas, observasi kelas dan pertemuan idividu. Teknik yang paling efektif untuk mengamati guru adalah kunjungan kelas, karena kepala sekolah dapat secara langsung melihat kesiapan administrasi, metode, ketrampilan guru dalam mengajar, serta melihat guru dalam memotivasi siswa dalam belajar. Selain itu, kepala sekolah dan pengasuh juga melakukan pengamatan terhadap guru yang sedang mengajar di luar kelas secara tidak terjadwal untuk mengamati proses pembelajaran. Apabila di dalam pengamatan terdapat masalah guru yang dihadapi dalam pelaksanaan proses pembelajaran, maka guru tersebut di panggil untuk melakukan pertemuan individu untuk diberikan bimbingan, dan berdiskusi untuk mencari jalan keluarnya terhadap masalah yang dihadapi.

\section{Tindak Lanjut Supervisi Akademik Kepala Sekolah dan Pengasuh Pondok Pesantren}

Tindak lanjut supervisi merupakan manfaat dari hasil supervisi. Berdasarkan temuan dilapangan hasil supervisi akademik yang dilakukan kepala sekolah dan pengasuh pondok pesantren itu sangat penting karena dapat ber pengaruh terhadap peningkatan proses pembelajaran. Program tindak lanjut yang diberikan oleh kepala sekolah dan pengasuh pondok pesantren pada guru PAI berupa pemantauan dan bimbingan secara terus menerus baik secara kelompok maupun secara individu. Hal ini seperti yang disampaikan oleh kepala MTs Pondok Pesantren Al-Mu'min bapak SS dalam wawancara: "Ada tindak lanjut yang kami lakukan adalah pemantauan, dan bimbingan baik secara kelompok maupun individu. Secara kelompok kami mengadakan rapat bulanan. Dalam rapat bulanan kami memberikan bimbingan, motivasi, dan penguatan kepada semua guru termasuk guru PAI. Kami juga mengadakan MGMP, ataupun workshop tergantung permasalahan yang kami temukan di lapangan. Kemudian kalau secara individu yang kami lakukan adalah dengan memanggil guru yang bersangkutan semisal pada saat disupervisi ada guru yang belum S1 guru tersebut kami panggil guru yang bersangkutan, memberikan 
saran dan motivasi untuk melanjutkan S1" (Data Wawancara dengan SS pada hari Rabu, 20 Februari 2019).

Pengasuh pondok pesantren Al-Mu'min Ustadz SR juga menyampaikan dalam wawancara: "Ya, tentunya ada setiap sebulan sekali kami melaksanakan bimbingan terhadap pimpinan kepala sekolah maupun terhadap guru PAI di sekolahan kami dan kami laksanakan secara terus menerus" (Data Wawancara dengan SR pada hari Rabu, 20 Februari 2019).

Hal yang terpenting dalam program tindak lanjut supervisi akademik kepala sekolah dan pengasuh pondok pesantren sasaranya adalah peningkatan proses pembelajaran. Dengan adanya tindak lanjut berupa pembinaan, pemantauan dan bimbingan yang berkelanjutan baik secara individu maupun kelompok, agar dapat memberikan solusi jalan keluar yang terbaik terhadap masalah dan kendala yang muncul dalam pembelajaran. Selain itu, guru dapat mengembangkan ketrampilan mengajarnya dengan ikut serta dalam pelatihan guru atau workshop dalam peningkatan ketrampilan

\section{E. Faktor Penghambat Pelaksanaan Supervisi Akademik}

Setiap kegiatan pasti ada kendalanya salah satunya kendala adalah faktor penghambat dari supervisi akademik yang dilakuakan kepala sekolah dan pengasuh pondok pesantren di MTs Pondok Pesantren Al-Mu'min Muhammadiyah Tembarak Temanggung adalah: pertama, waktu pelaksanaannya tidak sesuai dengan jadwal. Waktu yang telah dijadwalkan disetujui oleh kepala dan guru yang di supervisi ini berubah karena adanya kegiatan lain yang mendesak, seperti kepala sekolah tiba-tiba ada rapat mendadak ada rapat yang tidak boleh diwakilkan ke Kemenag, sehingga waktu pelaksanaanya harus undur. Kedua, Faktor kesehatan guru dan supervisor. Waktu yang telah dijadwalkan disetujui oleh kepala dan guru pada saat yang sama salah satu dari kepala atau gurusedang sakit sengga dalam pelaksanaan supervisi tidak maksimal. Ketiga, faktor sosial. Guru yang disupervisi usianya lebih tua dari supervisor. Sehingga dalam pelaksanaanya kurang maksimal. 
F. Fakor Pendukung Pelaksanaan Supervisi Akademik

Faktor

pendukung

pelaksanaan

supervisi

akademik

menjadi sebuah

kekuatan

penyemangat, dan dorongongan untuk melaksanakan program supervisi yang dilakukan kepala sekolah maupun pengasuh pondok pesantren. Dari keterangan hasil wawancara dengan kepala sekolah bapak SS dan pengasuh podok pesantren Ustadz SR faktor pendukung pelaksanaan supervisi akademik di MTs Pondok Pesantren Al-Mu'min yaitu: pertama faktor keterbukaan guru, guru sudah memahami bahwa supervisi adalah salah satu alat sebagai untuk peningkatan evaluasi proses pembelajaran. Kedua kepala sekolah dan pengasuh pondok pesantren dapat mengontrol, membimbing dan mengembangkan ketrampilan guru. Ketiga, kepala sekolah dan pengasuh pondok pesantren termotivasi karena untuk beribadah meningkatkan kualitas sumber daya manusia yang beriman dan bertaqwa.

\section{KESIMPULAN}

Berdasarkan pembahasan tentang supervisi akademik kepala sekolah dan pengasuh pondok pesantren di MTs Pondok Pesantren Al-Mu;min Muhammadiyah Tembarak Temanggung dapat diambil kesimpulan sebagai berikut: Metode supervisi akademik yang digunakan kepala sekolah dan pengasuh MTs Pondok Pesantren Al-mu'min, menggunakan metode pendekatan kolaboratif yaitu pendekatan langsung dan tidak langsung. Teknik supervisi yang digunakan, menggunakan dua teknik yaitu teknik individu dan kelompok. Teknik individu meliputi: kunjungan kelas, observasi dan pertemuan individu. Teknik kelompok dengan mengadakan rapat dan pelatihan guru untuk meningkatkan kompetensi guru.

Penerapan supervisi akademik di MTs Pondok Pesantren Al-Mu'min diterapkan kepada semua guru dan staf. Pelaksanaannya pada awal tahun ajaran baru, dan setiap bulan secara terjadwal maupun tidak terjadwal (insidental) dengan menggunakan metode pendekatan kolaboratif dan teknik kelompok maupun individu. 
Faktor penghambat dari supervisi akademik yang dilakuakan kepala sekolah dan pengasuh pondok pesantren di MTs Pondok Pesantren Al-Mu'min Muhammadiyah Tembarak Temanggung adalah (a) waktu pelaksanaannya kadangkadang tidak sesuai dengan jadwal, (b) faktor kesehatan guru dan supervisor, (c) Faktor sosial guru yang di supervisi lebih tua dari supervisor. Sedangkan faktor pendukungnya adalah (a) faktor keterbukaan guru, (b) kepala sekolah dan pengasuh pondok pesantren dapat mengontrol, membimbing dan mengembangkan ketrampilan guru, (c) kepala sekolah dan pengasuh pondok pesantren termotivasi karena untuk beribadah meningkatkan kualitas sumber daya manusia yang beriman dan bertaqwa.

\section{DAFTAR PUSTAKA}

Arikunto, Suharsimi \& Lia Yuliana. Manajemen Pendidikan. Yogyakarta: Aditya Media, 2008.

Arikunto, Suharsimi. Dasar-dasar supervisi. Jakarta: Rineka Cipta, 2004.

Dharma, Surya. Metode dan Tehnik Supervisi. Jakarta: Direktorat Tenaga Kependidikan Direktorat
Jenderal Peningkatan Mutu Pendidik Dan Tenaga Kependidikan, 2008.

Faturrohman, Muhamad. Belajar dan pembelajaran Membantu Meningkatkan Mutu Pembelajaran Sesuai Standar Nasional, Yogyakarta: Teras 2012.

Idi, Abdulah \& Toto Suharto. Revitalisasi Pendidikan Islam, Yogyakarta: Tiara Wacana, 2006.

Karwati, Euis \& Donni Juni Priansa. Kinerja dan Profesionalisme Kepala Sekolah. Bandung: Alfabeta, 2013.

Kementrian Agama RI. Al Qur"an dan Terjemahnya, Jakarta: PT. Sinergi Pustaka Indonesia, 2012.

Kompri. Manajemen Pendidikan. Bandung: Alfabeta, 2015.

Makawimbang, Jeri H. Kepemimpinan Pendidikan yang Bermutu, Bandung: Alfabeta, 2012.

Masaong, Abd. Kadim. Supervisi Pembelajaran dan Pengembangan Kapasitas Guru. Bandung: Afabeta, 2013.

Maunah, Binti. Supervisi Pendidikan Islam. Yogyakarta: Teras, 2009.

Mulyasa. Manajemen dan Kepemimpinan kepala Sekolah. jakarta: Bumi Aksara, 2013.

Prasojo, Lantip Diat \& Budiyono. Supervisi Pendidikan. 
Yogyakarta: Gava Media, 2011.

Priansa, Donni Juni \& Rismi Somad. Manajemen Supervisi dan Kepemimpinan Kepala Sekolah. Bandung: Alfabeta, 2014.

Sagala, Syaiful. Supervisi Pembelajaran Dalam Profesi Pendidikan Bandung: Alfabeta, 2012.

Snae, Yandri. D.I. dkk. Modul Kepala Sekolah Belajar Supervisi Akademik. Jakarta: Direktorat Jenderal Guru dan Tenaga Kependidikan, 2016. 
Al-Mudarris : Jurnal Ilmiah Pendidikan Islam

p-ISSN: 2662-1993

Vol. 2, No. 1, Mei 2019, pp. 91 - 108

e-ISSN: 2662-1586 